\title{
ANALISIS KESULITAN BELAJAR SISWA PADA MATERI JAMUR DI KELAS X IPA SMA N 1 BATANG KUIS
}

\author{
Dina Alfila Lubis ${ }^{1^{*}}$, Ashar Hasairin ${ }^{2}$, Rengkap ${ }^{3}$ \\ ${ }^{1,2}$ Program Studi Pendidikan Biologi, FMIPA, Universitas Negeri Medan, Medan Jl. Willem Iskandar Psr. V Medan Estate, \\ Medan,Indonesia, 20221 \\ ${ }^{3}$ SMA N 1 Batang Kuis, Jalan Pancasila, Gang Pendidikan, Kec. Batang Kuis, Kab. Deli Serdang 20372 \\ *E-mail : dinalubis28@gmail.com
}

\begin{abstract}
ABSTRAK
Penelitian ini bertujuan untuk mengetahui tingkat kesulitan siswa pada materi jamur di kelas X IPA SMA Negeri 1 Batang Kuis dan faktor-faktor penyebab kesulitan belajar. Populasi dalam penelitian ini adalah seluruh siswa kelas X IPA yang berjumlah 123 orang, dan sampel yang digunakan adalah seluruh populasi (sampel total). Penelitian ini berupa deskriptif kuantitatif. Instrumen yang digunakan dalam penelitian ini berupa tes objektif pada materi jamur yang berjumlah 30 soal dan angket yang berjumlah 40 item. Hasil penelitian diperoleh bahwa: (1)Kesulitan belajar siswa dalam mempelajari materi jamur dilihat dari aspek kognitif yang terendah terdapat pada tingkat C1 (mengingat) sedangkan yang kesulitan belajar yang tertinggi terdapat tingkat C6 (menciptakan); (2) Kesulitan belajar siswa dalam mempelajari materi jamur dilihat dari aspek indikator pembelajaran yang terendah terdapat pada indikator 1 yaitu mengidentifikasi ciri-ciri jamur dan yang kesulitan belajar yang tertinggi terdapat indikator 5 yaitu mengidentikasi jamur beracun dan tidak beracun (dapat dimakan); (3) Faktor tertinggi yang mempengaruhi kesulitan belajar siswa pada materi jamur adalah pelajaran dan faktor terendah yaitu kelas.
\end{abstract}

Kata kunci: Kesulitan belajar, Aspek kognitif, Indikator pembelajaran

\section{ABSTRACT}

The research aims to determine the level students' learning difficulty in fungi subject matter and affecting factors students' learning difficulties in class X IPA SMA Negeri 1 Batang Kuis. The population was all students X IPA SMA Negeri 1 Batang Kuis which amounted to 123 people, and the sample is all of students or total sample. This research was quantitative descriptive. Instrument of this research by using an objective test about fungi 30 questions and questionnaire which amounted to 40 items. The result show that: (1) The highest learning difficulties in fungi subject matter from cognitive aspect at level C6 (create) and the lowest at level C1 (remember); (2) The highest learning difficulties in fungi subject matter from learning indicator at indicator 5 (identifying the poisonous and edible fungi) and the lowest at indicator 1 (identifying general characteristics of fungi); (3) The highest factor affecting students' learning difficulties in fungi subject matter is lesson and lowest factor is class.

Keywords: Learning difficulties, Cognitive aspects, Learning indicators

\section{PENDAHULUAN}

Sekolah sebagai lembaga pendidikan memiliki peran penting dalam menentukan keberhasilan siswa. Keberhasilan maupun kegagalan proses pembelajaran akan terlihat dalam bentuk prestasi belajar dan perilaku siswa sebagai hasil belajar. Siswa yang berhasil dalam belajar akan mendapatkan prestasi belajar yang tinggi, sebaliknya siswa yang gagal dalam belajar akan mendapatkan prestasi belajar yang rendah. Ketika siswa gagal dalam belajar dapat dikatakan bahwa siswa tersebut mengalami kesulitan dalam belajar.
Materi jamur termasuk salah satu materi yang sulit untuk dipelajari oleh siswa. Pada materi jamur terdapat nama-nama ilmiah dan bahasa-bahasa latin yang harus dimengerti oleh siswa, hal ini menjadi salah satu penyebab siswa mengalami kesulitan dalam mempelajari materi jamur. Menurut Fathonatun dkk (2016) materi jamur memiliki subpokok bahasan yang harus mampu dipelajari dan dipahami oleh siswa seperti tahapan-tahapan siklus hidup dari masingmasing divisi, perbedaan ciri-ciri morfologi, dan cara memperoleh nutrisi.

Menurut Tsabari, dkk (2010) topik mikrobiologi memiliki ketertarikan yang rendah dibandingkan topik 
lain yang ada di biologi. Hal ini bisa terlihat hanya 5,9\% (1676 dari 28484) partisipan yang memilih topik tersebut. Materi jamur merupakan bagian dari mikrobiologi, sehingga dapat dikatakan bahwa materi jamur memiliki ketertarikan yang rendah. Hal ini diperkuat dari hasil penelitian yang dilakukan oleh Goldberg dan Ingram (2011) bahwa dari 33 responden, $100 \%$ familiar dengan topik fotosintesis, $97 \%$ familiar dengan topik mitosis dan meiosis, $67 \%$ familiar dengan topik siklus hidup tanaman dan $70 \%$ familiar dengan topik keanekaragaman tanaman, dan hanya $52 \%$ orang yang familiar dengan topik tanaman yang berukuran seluler seperti alga dan fungi. Hasil penelitian Musriadi dan Rubiah (2016) menunjukkan 65 siswa sulit memahami konsep dan masalah yang berkaitan dengan materi jamur. Siswa membutuhkan pengembangan bahan pembelajaran dan kesesuaian serta pengorganisasian materi sebagai solusi dari masalah pada jamur.

Berdasarkan hasil analisis angket yang dilakukan oleh Darmawilis, dkk (2014) mengenai faktor kesulitan belajar pada materi jamur $38 \%$ berasal dari siswa, 30,8\% berasal dari guru, 53,3\% berasal dari buku teks. Hal ini juga dibuktikan oleh Hasruddin dan Putri (2014) bahwa faktor yang mempengaruhi kesulitan belajar siswa pada materi jamur berasal dari 51,22\% kesehatan, 49,44\% psikiatrik, 53,38\% inteligensi, 55,90\% motivasi, 65,17 $\%$ keadaan rumah, 64,3 \% guru, 73,03\% lingkungan sekolah, 67,98\% konteks pelajaran, 67,01\% media, $68,97 \%$ lingkungan rumah, dan $86,67 \%$ orang tua.

Kesulitan belajar yang dialami siswa pada materi jamur dapat dilihat dari hasil wawancara yang dilakukan dengan salah satu guru biologi di SMA Negeri 1 Batang Kuis menyebutkan bahwa 60\% (74 dari 124) siswa memperoleh nilai di bawah KKM (< 75). Kesulitan yang dialami siswa salah satunya disebabkan oleh keterbatasan buku pegangan, media yang digunakan guru saat mengajar materi jamur belum memadai, alat dan bahan yang terdapat di laboratorium kurang lengkap untuk digunakan dalam proses pembelajaran. Hal ini juga diperkuat dari hasil penelitian yang dilakukan oleh Al-Firdausi (2015) yang membuktikan bahwa terdapat 27 (64,19\%) siswa tidak tuntas dan 15 (35,71\%) siswa tuntas dalam mempelajari materi jamur.

Tujuan penelitian ini adalah untuk mengetahui hasil belajar siswa dari aspek kognitif pada materi jamur kelas X IPA SMA N 1 Batang Kuis, untuk mengetahui kesulitan belajar aspek kognitif siswa pada materi jamur kelas X IPA SMA N 1 Batang Kuis, dan untuk mengetahui faktor-faktor penyebab kesulitan belajar siswa pada materi jamur kelas X IPA SMA N 1 Batang Kuis.

\section{METODE PENELITIAN}

Penelitian ini dilaksanakan di SMA N 1 Batang Kuis yang beralamat di Jalan Pancasila Gang Pendidikan Kecamatan Batang Kuis, Kabupaten Deli Serdang Provinsi Sumatera Utara Kode pos 20372 pada bulan Maretl sampai Mei Tahun 2017. Populasi dalam penelitian ini adalah seluruh siswa kelas $X$ IPA SMA N 1 Batang Kuis yang yang berjumlah 123 orang, dan sampel dalam penelitian ini adalah seluruh populasi (sampel total). Jenis Penelitian ini merupakan penilitian deskriptif kuantitatif.

Instrumen yang digunakan dalam penelitian ini adalah tes objektif dan angket. Tes yang digunakan dalam bentuk tes objektif yang berbentuk pilihan berganda sebanyak 30 soal berdasarkan hasil validasi terhadap 40 soal yang diujikan terhadap 35 siswa, dengan 5 pilihan soal (a, b, c, d, e). Setiap satu jawaban yang benar diberi skor 1. Angket kesulitan belajar siswa dibuat berdasarkan faktor internal dan faktor ekternal dari kesulitan belajar yang dialami oleh siswa yang terdiri dari 30 soal dengan menggunakan skala guttman. Kisi-kisi tes objektif dapat dilihat pada Tabel 1. 
Tabel 1. Kisi-Kisi Soal Tes Objektif

\begin{tabular}{|c|c|c|c|c|c|c|c|c|}
\hline \multirow[b]{2}{*}{ Materi } & \multirow[b]{2}{*}{ Indikator Pembelajaran } & \multicolumn{6}{|c|}{ Nomor Soal Untuk Kategori } & \multirow[b]{2}{*}{ Tota } \\
\hline & & $\mathrm{C}_{1}$ & $\mathrm{C}_{2}$ & $\mathrm{C}_{3}$ & $\mathrm{C}_{4}$ & $\mathrm{C}_{5}$ & $\mathrm{C}_{6}$ & \\
\hline \multirow{7}{*}{ Jamur } & $\begin{array}{l}\text { Mengidentifikasi ciri-ciri jamur secara } \\
\text { umum }\end{array}$ & $\begin{array}{l}7 \\
28\end{array}$ & $\begin{array}{l}1, \\
30\end{array}$ & $\begin{array}{l}3 \\
15\end{array}$ & & & & 6 \\
\hline & $\begin{array}{l}\text { Mendeskripsikan perbedaan dari setiap } \\
\text { jamur }\end{array}$ & 21 & 11 & 14 & 12 & & & 4 \\
\hline & $\begin{array}{l}\text { Mengelompokkan jamur berdasarkan } \\
\text { karakteristiknya }\end{array}$ & 16 & 10 & $\begin{array}{l}17, \\
19\end{array}$ & & & & 4 \\
\hline & $\begin{array}{l}\text { Mendeskripsikan reproduksi pada } \\
\text { jamur }\end{array}$ & 9 & $\begin{array}{l}6, \\
23\end{array}$ & & 27 & & & 4 \\
\hline & $\begin{array}{l}\text { Mengidentifikasi jamur beracun dan } \\
\text { tidak beracun (dapat dimakan) }\end{array}$ & 4 & 2 & 20 & & 29 & 24 & 5 \\
\hline & $\begin{array}{l}\text { Menyimpulkan peranan jamur dalam } \\
\text { kehidupan sehari-hari }\end{array}$ & $\begin{array}{c}5 \\
13,2 \\
6 \\
\end{array}$ & $\begin{array}{l}8, \\
18\end{array}$ & 22 & 25 & & & 7 \\
\hline & Total & 9 & 9 & 7 & 3 & 1 & 1 & 30 \\
\hline
\end{tabular}

Soal disusun berdasarkan kriteria penyusunan soal dari segi taraf kompetensinya menurut Sudijono (2013) yaitu taraf mengingat $\left(C_{1}\right)=35 \%$, taraf memahami $\left(C_{2}\right)=25 \%$, taraf menerapkan $\left(C_{3}\right)=20 \%$, taraf menganalisis $\left(C_{4}\right)=10 \%$, taraf mengevaluasi $\left(C_{5}\right)$ $=5 \%$ dan taraf menciptakan $\left(\mathrm{C}_{6}\right)=5 \%$. Kaidah penskoran pada tes ini yaitu, siswa yang nilai hasil tesnya memenuhi $(\geq 75)$ tidak diikutsertakan dalam pengisian angket, sedangkan siswa yang nilai hasil tesnya dibawah KKM (<75) diikutsertakan pengisian angket.

Prosedur penelitian terdiri tiga tahapan yaitu tahap persiapan, tahap pelaksanaan dan tahap pengolahan data. Pada tahap persiapan dilakukan observasi ke sekolah dan penyusunan instrument penelitian. Pada tahap pelaksanaan dilakukan penyebaran soal dan angket bagi siswa yang hasil tesnya tidak memenuhi KKM. Pada tahap pengolahan data dilakukan analisis data terhadap hasil belajar dan angket siswa untuk mengetahui hasil belajar, kesulitan belajar, dan faktor penyebab kesulitan belajar.

Adapun teknik analisis data yang digunakan adalah metode sekriptif kuantitatif. Secara deskriptif dimaksudkan untuk memberikan jawaban terhadap rumusan masalah yaitu mengenai kesulitan belajar siswa pada materi jamur dan faktor-faktor penyebabnya. Untuk menentukan tingkat kesulitan belajar siswa dalam memahami materi jamur dapat diperoleh dari penggunaan rumus daya serap siswa pada setiap aspek kognitif (C1-C6 dan indikator pembelajaran) dengan rumus sebagai berikut.

Daya Serap $=\frac{\text { Skor Total Tiap Item }}{\text { Nx Bobot }} \times 100 \%$

Setelah memperoleh daya serap siswa dalam bentuk persentase pada setiap aspek kognitif (C1-C6 dan indikator pembelajaran) maka diperoleh persentase kesulitan belajar dengan cara 100\% - Daya Serap. Maka akan diperoleh kriteria ketuntasan belajar berdasarkan kategori Tabel 2. Analisis data angket digunakan dengan mencari persentase dari setiap variabel yang diteliti dan data yang diungkapkan dalam penelitian yang berupa jawaban pertanyaan yang ada pada rumusan masalah dengan memberikan angket. Untuk mendapatkan persentase dari setiap variabel yaitu menggunakan rumus persentase respons siswa (Trianto, 2013) yaitu:

Persentase respons siswa $=\frac{A}{B} \times 100 \%$

Dimana,

$A=$ Proporsi siswa yang memilih

$B=$ Jumlah siswa (responden) 
Tabel 2. Kategori Tingkat Kesulitan Berdasarkan Persentase

\begin{tabular}{cc}
\hline Tingkat Kesulitan (\%) & Kriteria Kesulitan \\
\hline $0-20$ & Sangat rendah \\
$21-40$ & Rendah \\
$41-60$ & Sedang \\
$61-80$ & Tinggi \\
$81-100$ & Sangat tinggi \\
\hline
\end{tabular}

(Riduwan dan Akdon, 2007)

Setelah didapatkan persentase setiap variabel lalu diinterpretasikan data dengan tabel pengaruh kesulitan belajar.

Tabel 3. Kategori Tingkat Pengaruh Faktor Kesulitan Belajar

\begin{tabular}{cc}
\hline Tingkat Pengaruh (\%) & Kriteria Pengaruh \\
\hline $0-20$ & Sangat rendah \\
$21-40$ & Rendah \\
$41-60$ & Sedang \\
$61-80$ & Tinggi \\
$81-100$ & Sangat tinggi \\
\hline
\end{tabular}

(Riduwan dan Akdon, 2007)

\section{HASIL PENELITIAN}

Hasil tes menunjukkan bahwa dari 123 siswa yang dijadikan sampel penelitian, sebanyak 16 siswa nilai tesnya dinyatakan memenuhi KKM ( $\geq 75$ ) yang diharapkan, berarti ada sebanyak 107 siswa yang nilainya dinyatakan tidak memenuhi KKM (<75). Setelah didapatkan sebaran nilai dan jumlah total perkalian jumlah frekuensi dengan nilai hasil tes diperoleh rata-rata nilai hasil tes adalah 52,32.

Hasil penelitian menunjukkan bahwa tingkat kesulitan belajar siswa pada aspek kognitif termasuk dalam kategori sedang dengan rata-rata persentase kesulitan sebesar 58,08\%. Adapun penjabaran dari setiap level kognitif tersebut dijabarkan pada Tabel 4.

Tabel 4 Distribusi Tingkat Kesulitan Belajar Siswa Pada Aspek Kognitif

\begin{tabular}{ccccccc}
\hline No & $\begin{array}{c}\text { Aspek } \\
\text { Kognitif }\end{array}$ & $\begin{array}{c}\text { Skor } \\
\text { Ideal }\end{array}$ & $\begin{array}{c}\text { Skor } \\
\text { Capaian }\end{array}$ & Daya Serap (\%) & $\begin{array}{c}\text { Kesulitan Belajar } \\
\text { Siswa (\%) }\end{array}$ & $\begin{array}{c}\text { Kategori Tingkat } \\
\text { Kesulitan }\end{array}$ \\
\hline 1 & C1 & 1107 & 623 & $56,27 \%$ & $43,73 \%$ & Sedang \\
2 & C2 & 1107 & 529 & $47,78 \%$ & $52,22 \%$ & Sedang \\
3 & C3 & 861 & 397 & $46,10 \%$ & $53,90 \%$ & Sedang \\
4 & C4 & 369 & 146 & $39,56 \%$ & $60,44 \%$ & Tinggi \\
5 & C5 & 123 & 42 & $34,14 \%$ & $65,86 \%$ & Tinggi \\
6 & C6 & 123 & 34 & $27,64 \%$ & $72,36 \%$ & Tinggi \\
\hline \multicolumn{7}{c}{ Rata-rata }
\end{tabular}

Hasil penelitian juga menunjukkan bahwa tingkat kesulitan belajar siswa pada indikator pembelajaran termasuk dalam kategori sedang dengan rata-rata persentase kesulitan sebesar 50,02\%. Adapun penjabaran dari setiap indikator pembelajaran tersebut dijabarkan pada Tabel 5. 
Halaman : $340-347$

Tabel 5. Distribusi Tingkat Kesulitan Belajar Siswa di Setiap Indikator Pembelajaran Pada Materi Jamur

\begin{tabular}{|c|c|c|c|c|c|c|}
\hline No & $\begin{array}{c}\text { Indikator } \\
\text { Pembelajaran }\end{array}$ & $\begin{array}{l}\text { Skor } \\
\text { Ideal }\end{array}$ & $\begin{array}{l}\text { Skor } \\
\text { Capaian }\end{array}$ & $\begin{array}{c}\text { Daya } \\
\text { Serap (\%) }\end{array}$ & $\begin{array}{l}\text { Kesulitan } \\
\text { Belajar } \\
\text { Siswa (\%) }\end{array}$ & $\begin{array}{c}\text { Kategori } \\
\text { Tingkat } \\
\text { Kesulitan }\end{array}$ \\
\hline 1 & $\begin{array}{l}\text { Mengidentifikasi ciri-ciri jamur } \\
\text { secara umum }\end{array}$ & 738 & 427 & $57,85 \%$ & $42,05 \%$ & Sedang \\
\hline 2 & $\begin{array}{l}\text { Mendeskripsikan perbedaan dari } \\
\text { setiap kelompok jamur }\end{array}$ & 492 & 242 & $44,18 \%$ & $50,82 \%$ & Sedang \\
\hline 3 & $\begin{array}{l}\text { Mengelompokkan jamur } \\
\text { berdasarkan karakteristiknya }\end{array}$ & 492 & 262 & $53,25 \%$ & $46,75 \%$ & Sedang \\
\hline 4 & $\begin{array}{l}\text { Mendeskripsikan reproduksi pada } \\
\text { jamur }\end{array}$ & 492 & 221 & $55,04 \%$ & $45,7 \%$ & Sedang \\
\hline 5 & $\begin{array}{l}\text { Mengidentifikasi jamur beracun dan } \\
\text { tidak beracun (dapat dimakan) }\end{array}$ & 615 & 204 & $33,17 \%$ & $66,83 \%$ & Tinggi \\
\hline 6 & $\begin{array}{l}\text { Menyimpulkan peranan jamur dalam } \\
\text { kehidupan sehari-hari }\end{array}$ & 861 & 448 & $52,03 \%$ & $47,97 \%$ & Sedang \\
\hline \multicolumn{5}{|c|}{ Rata-rata } & $52,02 \%$ & Sedang \\
\hline
\end{tabular}

Setelah angket diberikan kepada siswa, maka data hasil angket dikelompokkan sesuai indikator kesulitan belajar yang diukur dari faktor internal dan faktor eksternal Hasilnya dapat dilihat pada Tabel 6.

Tabel 6 Kontribusi Terhadap Kesulitan Belajar Siswa Berdasarkan Indikator Penyebab Kesulitan Belajar

\begin{tabular}{clcc}
\hline No & Faktor & Rata-rata Siswa yang Memilih (\%) & Kategori Pengaruh Kesulitan Belajar \\
\hline 1 & Jasmaniah & 32,25 & Rendah \\
2 & Psikologis & 48,29 & Sedang \\
3 & Orang tua & 68,78 & Tinggi \\
4 & Rumah & 44,39 & Sedang \\
5 & Guru & 43,55 & Sedang \\
6 & Pelajaran & 73,84 & Tinggi \\
7 & Kelas & 24,30 & Rendah \\
8 & Lingkungan sekolah & 54,39 & Sedang \\
9 & Lingkungan rumah & 40,19 & Sedang \\
\hline
\end{tabular}

Dari Tabel 6 diperoleh hasil dari setiap faktor penyebab kesulitan belajar siswa. Faktor pelajaran memiliki persentase tertinggi sebesar $73,84 \%$ sehingga dapat dikategorikan bahwa isi dari materi jamur menjadi penyebab utama kesulitan belajar siswa. Sedangkan faktor kelas memiliki persentase terendah dengan persentase sebesar $24,30 \%$ ini berarti bahwa faktor kelas sangat rendah mempengaruhi kesulitan belajar siswa pada materi jamur.

\section{PEMBAHASAN}

Berdasarkan hasil penelitian yang dilakukan aspek kognitif C1 memiliki tingkat kesulitan belajar yang terendah dibandingkan dengan tingkat kesulitan pada aspek kognitif lainnya. Untuk aspek kognitif C1 
tingkat kemampuan berpikir yang digunakan siswa masih dalam tingkat kemampuan berpikir yang rendah. Menurut Huit (2011) dalam beberapa kasus terbukti bahwa siswa dapat mengetahui suatu topik atau materi pelajaran dalam cara dan level yang berbeda. Untuk menjawab soal tingkat C1 siswa hanya perlu mengingat kembali materi jamur yang telah diajarkan sebelumnya oleh guru. Hal ini sesuai dengan pendapat Siregar dan Nara (2010) bahwa mengingat yaitu meningkatkan ingatan atas materi yang disajikan dalam bentuk yang sama seperti yang diajarkan.

Aspek kognitif C2 memiliki tingkat kesulitan belajar yang lebih tinggi dibandingkan dengan tingkat kesulitan pada aspek kognitif $\mathrm{C} 1$, karena pada aspek kognitif C2 siswa mulai dituntut untuk dapat memahami makna dari pembelajaran yang pernah dipelajari pada materi jamur. Untuk menjawab soal tingkat C3 siswa perlu menggunakan teori-teori dan prinsip-prinsip materi jamur yang telah diajarkan sebelumnya oleh guru untuk menjawab masalah baru (Sudijono, 2013).

Aspek kognitif C4 memiliki tingkat kesulitan belajar yang lebih tinggi dibandingkan dengan tingkat kesulitan pada aspek kognitif C3, C2 dan C1. Menurut Winkel (2009) pada aspek kognitf C4 siswa dituntut untuk dapat menganalisis dan memahami hubungan antara bagian-bagian materi pembelajaran yang pernah dipelajari sebelumnya. Untuk menjawab soal tingkat C5 siswa perlu mempertimbangkan suatu kriteria tertentu yang berkaitan dengan materi jamur dengan teori yang telah diajarkan sebelumnya oleh guru (Kunandar, 2011). Dalam penelitian ini soal tingkat C5 berkaitan dengan mengidentifikasi jamur beracun dan jamur tidak beracun, siswa harus mampu memberikan penilaian berdasarkan kriteria yang ada pada soal untuk menentukan ciri-ciri yang tepat dengan jenis jamur yang ada.

Aspek kognitif C6 memiliki tingkat kesulitan belajar yang paling tinggi dibandingkan aspek kognitif lainnya. Pada aspek kognitf C6 siswa dituntut untuk dapat menyusun elemen-elemen menjadi produk yang baru terhadap materi jamur yang pernah dipelajari sebelumnya (Siregar dan Nara, 2010). Untuk aspek kognitif C6 tingkat kemampuan berpikir yang digunakan siswa sudah dalam tingkat kemampuan berpikir yang tinggi. Menurut Utari, dkk (2012) bahwa semakin tinggi ranah kognitifnya, maka semakin sulit kemampuan berpikirnya. Dalam penelitian ini soal tingkat C6 berkaitan dengan mengidentifikasi jamur beracun dan jamur tidak beracun, siswa harus mampu merencanakan hal yang akan dilakukan jika terjadi suatu masalah yang berkaitan dengan jamur beracun dan tidak beracun.

Selain aspek kognitif tingkat kesulitan belajar siswa pada materi jamur juga dilihat dari indikator pembelajaran yaitu diketahui bahwa 57,85\% siswa mampu menyerap pelajaran pada indikator (1) sehingga dapat dikategorikan bahwa indikator (1) sangat mudah dipahami oleh siswa. Indikator (1) lebih mudah untuk dijawab siswa karena pada indikator (1) siswa hanya dituntut mempelajari ciri-ciri umum pada jamur dan siswa tidak harus menggunakan kemampuan yang tinggi untuk memahami indikator tersebut. Dan 33,17\% siswa mampu menyerap pelajaran pada indikator (5) sehingga dapat dikategorikan bahwa indikator (5) sulit dipahami oleh siswa. Indikator (5) sangat sulit untuk dijawab siswa karena pada indikator (5) siswa harus dapat mengidentifikasi suatu jamur beracun atau tidak. Untuk mengidentifikasi suatu jamur beracun atau tidak membutuhkan kemampuan yang tinggi karena jamur beracun dan tidak beracun kebanyakan memiliki morfologi yang sama.

Setelah dilakukan hasil analisis terhadap angket didapatkan bahwa faktor pelajaran memiliki persentase sebesar $73,84 \%$ dan termasuk kategori tinggi yang mempengaruhi kesulitan belajar siswa. Hasil penelitian ini menunjukkan bahwa hampir seluruh siswa SMA Negeri 1 Batang Kuis mengalami kesulitan dalam belajar dipengaruhi faktor pelajaran. $\mathrm{Hal}$ ini sejalan dengan hasil penelitian yang dilakukan oleh Umiyati dan Susilo (2014) bahwa materi pelajaran menjadi faktor tertinggi yang menyebabkan kesulitan belajar yaitu sebesar 48,97\% dan 45,86\%. Dalam materi jamur siswa dituntut untuk menghapal nama-nama latin. Nama-nama latin tersebut masih terdengar asing bagi siswa sehingga mereka sulit untuk mengahapal dan memahami materi tersebut. Menurut Makmun (2009) rata -rata peserta didik menganggap materi jamur sendiri tidak menarik, 
sehingga minat peserta didik untuk belajar berkurang. Peserta didik juga merasa materi yang disampaikan tidak begitu bermakna, sehingga tidak wajib untuk dipelajari. Kesulitan belajar peserta didik berhubungan dengan materi dan tingkat kesukarannya.

Faktor kelas memiliki persentase sebesar 24,30\% dan termasuk kategori rendah terhadap kesulitan belajar siswa. Hasil penelitian ini menunjukkan bahwa hanya sebagian kecil siswa SMA Negeri 1 Batang Kuis mengalami kesulitan dalam belajar dipengaruhi faktor kelas. Faktor kelas memiliki persentase terendah sehingga dapat dikategorikan kurang mempengaruhi kesulitan belajar siswa. Untuk faktor kelas terdiri dari indikator keadaan kelas. Keadaan kelas di SMA Negeri 1 Batang Kuis sudah memadai dan tidak memiliki kerusakan bangunan. Letak sekolah yang jauh dari pusat kota membuat suasana belajar yang nyaman dan tidak adanya kebisingan dari kendaraan umum. Mlambo (2011) berpendapat bahwa ukuran kelas menjadi salah satu faktor yang berdampak pada hasil belajar siswa.Menurut Siregar dan Nara (2010) jika keadaan gedung kelas sudah tua dan tidak direnovasi, serta kenyamanan dan kebersihan di dalam kelas yang masih kurang akan menghambat kondisi belajar siswa.

\section{KESIMPULAN}

Berdasarkan hasil dan pembahasan tersebut di atas, maka dapat disimpulkan sebagai berikut bahwa hasil belajar siswa dalam mempelajari materi jamur pada aspek kognitif termasuk pada kategori sedang dengan persentase capaian siswa sebesar $41,92 \%$ dan pada indikator pembelajaran termasuk pada kategori sedang dengan persentase capaian siswa sebesar 47,56\%. Kesulitan belajar siswa dalam mempelajari materi jamur pada aspek kognitif termasuk dalam kategori sedang dengan persentase rata-rata kesulitan pada aspek kognitif sebesar 58,08\% dan indikator pembelajaran sebesar 50,02\%. Faktor tertinggi yang mempengaruhi kesulitan belajar siswa yaitu pelajaran dengan persentase sebesar $73,84 \%$, sedangkan faktor terendah yaitu keadaan kelas dengan persentase sebesar $24,30 \%$.

\section{UCAPAN TERIMA KASIH}

Terima kasih terkhusus Bapak Drs. Ramlan Lubis, M.Pd. selaku Kepala Sekolah SMA N 1 Batang Kuis, yang telah membantu saya dalam melakukan penelitian ini dan siswa-siswi kelas $X$ IPA SMA $N 1$ Batang Kuis yang telah banyak membantu selama penelitian berlangsung.

\section{DAFTAR PUSTAKA}

Al-Firdausi, N. F., (2015), Hasil Penelitian Biologi (Studi Keanekaragaman Jamur Basidiomycota) Sebagai Sumber Belajar Materi Fungi SMA Kelas X SMA Muhammadiyah Ambon, Jurnal Horizon Pendidikan, 10 (2): 157-162.

Darmawilis, Budiarti, R. S. Gardjito, (2014), Analisis Kesulitan Belajar Siswa Kelas X IPS dalam Memahami Konsep pada Pokok Bahasan Fungi di SMA Negeri 11 Kota Jambi, Biologi PMIPA UNJA, 1-10.

Fathonatun, N., Isnawati, Guntur, T., (2016), Pengembangan Permainan Question Wheel Sebagai Media Pembelajaran Untuk Melatih Keaktifan Menjawab dan Meningkatkan Hasil Belajar Siswa Pada Materi Jamur, BioEdu, 5(3): 271-276.

Goldberg, N.A., dan Ingram, K.W., (2011), Improving Student Engagement in a Lower-Division Botany Course, Journal of the Scholarship of Teaching and Learning, 11(2): 76-90.

Hasruddin dan Putri, S. E., (2014), Analysis of Students' Learning Difficulties in Fungi Subject Matter Grade X Science of Senior High School Medan Academic Year 2013/2014, International Journal of Education and Research, 2(8): 269-276.

Huitt, W., (2011), Bloom et al.'s taxonomy of the cognitive domain. Educational Psychology Interactive, Valdosta, GA Valdosta State University.

Kunandar, (2011), Guru Profesional Implementasi Kurikulum Tingkat Satuan Pendidikan (KTSP) dan Sukses dalam Sertifikasi Guru, Rajawali Pers, Jakarta. 
Halaman : $340-347$

Makmun, A. S., (2009), Psikologi Kependidikan: Perangkat Sistem Pengajaran Modul, PT Remaja Rosda Karya, Bandung.

Mlambo, (2011), An Analysis of Some Factors Affecting Student Academic Performance in an Introductory Biochemistry Course at the University of the West Indies, Carribean Teaching Scholar, 1(2), 79-92.

Musriadi, dan Rubiah, (2016), Implementation of Problem Based Learning Model in Concept Learning Mushroom as a Result of Student Learning Improvement Efforts Guidelines for Teachers, Journal of Education and Practice, 7(22): 26-30.

Riduwan, dan Akdon, (2007), Rumus dan Data dalam Analisis Statistika, Alfabeta, Bandung.

Siregar dan Nara, (2010), Teori Belajar dan Pembelajaran, Ghalia Indonesia, Bogor.

Sudijono, A., (2013), Pengantar Evaluasi Pendidikan, Raja Grafindo Persada, Jakarta.

Trianto, (2013), Mendesain Model Pembelajaran Inovatif-Progresif, Kencana Prenada Media Group, Jakarta.

Tsabari, A.B., Sethi, R.J., Bry, L., dan Yanden, A., (2010), Identifying Students' Interests In Biology Using a Decade of Self-Generated Questions, Eurasia Journal of Mathematics, Science \& Technology Education, 6(1): 63-75.

Umiyati, D., dan Susilo, J., (2014), Perbandingan faktor-faktor Penyebab Kesulitan Belajar antara Siswa Kelas X.6 dengan Kelas X.7 pada Mata Pelajaran Biologi Materi Virus (Study Kasus di SMAN 1 Sukagumiwang - Indramayu), JUPEMASI P.BIO, 1(1): 106-108.

Utari, R., Madya, W., KNPK, P., (2012), Taksonomi Bloom Apa dan Bagaimana Menggunakannya, Taksonomi\%2520Bloom\%2520-\%2520Retnook- mima.pdf, diakses tanggal 25 Mei 2017.

Winkel, W.S., (2009), Psikologi Pengajaran, Media Abadi, Yogyakarta. 